\title{
SEJARAH PEMIKIRAN EKONOMI ISLAM
}

Nur Hikmah (90100118014)

Pemikiran ekonomi Islam muncul bersamaan dengan wahyu Al-Qur'an dan kehidupan Nabi pada akhir abad keenam hingga awal abad ketujuh. Penerapan sistem ekonomi Islam sudah ada dan Nabi Muhammad menjadikannya panutan bagi umat Islam. Bahkan orang Arab sudah dikenal sebagai bangsa pedagang sebelum masa Nabi Muhammad SAW.(Ibnudin, 2019) Sepeninggal Rasulullah SAW, Abu Bakar terus mengamalkan ekonomi Islam dengan mengutamakan pembayaran Zakat. Bersikap tegas dan melawan suku yang menolak membayar zakat. Di bawah Umar, praktik ekonomi Islam semakin luas dan maju seiring dengan penaklukan negara-negara di sekitar Jazirah Arab yang meliputi Roma timur (Suriah, Palestina, dan Mesir) dan seluruh Persia termasuk Irak, pusat Islam. Economie. Praktik di bawah Umar adalah pemerintahan Bitul, di mana pusat perbelanjaan dan pajak administrasi pertanahan (kharaj) disita dari negara-negara yang ditaklukkan. Di bawah Usman, dia mengadopsi kebijakan tidak mengambil gaji dari kantornya. Sebaliknya, justru meringankan beban pemerintah dalam hal-hal yang membahayakan, bahkan menyimpan uangnya di kas negara. Pada zaman Ali bin Abi Aliib, pajak untuk pemilik hutan adalah 4000 dirham dan Ibnu Abbas, Wali dari Kufah, diperbolehkan memungut pajak sedekah dari sayuran segar untuk digunakan sebagai bumbu masakan. Sementara dalam pemerintahannya, ia berprinsip bahwa penyaluran dana masyarakat sesuai dengan kemampuannya. (Kharidatul Mudhiiah, 2015)

Peter Gran memetakan perkembangan sejarah ekonomi Islam dalam lima tahap. Fase pertama yang disebut "Era Jahiliyya" berlanjut hingga tahun $660 \mathrm{M}$, ketika pola ekonomi masih didominasi oleh gaya Badui. Tahap kedua, tahun 660-950, disebut era negara kesukuan pertanian, di mana masyarakat pada umumnya berubah dari cara hidup nomaden menjadi gaya hidup pertanian. Tahap ketiga, antara tahun 950-1550, disebut era negara dagang yang membayar upeti karena kegiatan ekonomi pada masa itu didominasi oleh kegiatan komersial. Tahap keempat, 1550-1850, merupakan periode dimana aktivitas kerajaan samudra terbentuk, ditandai dengan kecenderungan masyarakat untuk meninggalkan gaya hidupnya di koloni kecil dan membentuk koloni yang lebih besar dalam bentuk kerajaan. Tahap kelima, dari tahun 1850 hingga sekarang disebut Era Kapitalisme di pinggiran. (Sirajuddin, 2016)

Dalam sejarah ekonomi yang ditulis oleh sejarawan Barat diasumsikan bahwa periode 
antara Yunani dan Skolastik adalah steril dan tidak produktif. Joseph Schumper menggambarkannya sebagai contoh "jurang pemisah yang besar" dalam sejarah pemikiran ekonomi. Penulisan sejarah ekonomi dimulai dengan para filsuf Yunani dan segera melewati 500 tahun ke pemikir skolastik Saint Thomas Aquinas, dan periode ini disebut kekosongan kegelapan era Barat. Ini sama sekali mengabaikan peran Muslim.

Jika proses evolusi ini terwujud, Chumber berargumen bahwa Schumper tidak boleh berasumsi bahwa jarak 500 tahun yang sangat besar itu adalah periode yang tidak produktif, tetapi akan mencoba menemukan fondasi di mana para sarjana Barat dan filsuf skolastik membangun struktur intelektual mereka. Hal ini dikarenakan dua poin yang hilang dalam sejarah pemikiran ekonomi, yaitu: jurang yang sangat besar di Abad Kegelapan dan hubungan antara pemikiran di Barat dan dunia Islam. (Istiqomah et al., 2019)

\section{EKONOMI KAPITALIS}

Sistem ekonomi kapitalis telah menjadi sistem ekonomi yang mendominasi sistem ekonomi yang digunakan negara saat ini. Walaupun perkembangan teknologi dan informasi atau teknologi informasi saat ini sangat pesat, dapat dikatakan belum ada sistem ekonomi kapitalis yang murni, karena negara kapitalis lebih sosialis daripada negara yang menggunakan sistem ekonomi sosialis yang sama. (Thoin, 2015)

\section{EKONOMI SOSIALIS}

Sistem ekonomi ini merupakan bentuk perlawanan dari sistem ekonomi sebelumnya, yaitu sistem ekonomi kapitalis. Pasalnya, sistem ekonomi kapitalis dituding tidak hanya mencapai kesejahteraan sosial. Sistem ekonomi sosialis adalah kebalikan dari sistem ekonomi kapitalis, yang menyerahkan semua siklus ekonomi sepenuhnya kepada mekanisme pasar yang ada. Adapun sistem ekonomi sosialis, dimana pemerintah berperan sangat besar dalam mengatur roda perekonomian dari sumber ke hilir dalam mata rantai ekonomi masyarakat.

Sistem ekonomi sosialis tidak berarti tidak memberikan kebebasan individu dalam kegiatan ekonomi. Individu masih menikmati kebebasan untuk melakukan kegiatan ekonomi, tetapi sangat terbatas, dan dengan intervensi pemerintah yang sangat besar, pemerintah melakukan intervensi untuk mencapai kemakmuran rakyat dan negara. 


\section{DAFTAR PUSTAKA}

Muhammad Tho`in. (2015). Konsep Ekonomi Islam Jalan Tengah (Kapitalis - Sosialis). Jurnal Ilmiah Ekonomi Islam. 01(03), 118-133.

Istiqomah, L., Islam, P. E., \& Global, E. (2019). Jurnal Al-Iqtishod Jurnal Al-Iqtishod. 1(1), $1-19$.

Kharidatul Mudhiiah. (2015). Analisis Sejarah Pemikiran Ekonomi Islam Masa Klasik. Iqthishadia, 8(2), 189-210.

Sirajuddin, (2016). Konsep Pemikiran Ekonomi Al-Ghazali. Laa Maisyir. 3(1), 47-60.

Ibnudin, (2019). Pemikiran Ekonomi Islam Pada Masa Nabi. Risalah 5(1), 51-61. 